\title{
Conception of Religion Teacher in Bugis Makassar Cultural Context
}

\author{
Firdaus $^{1 *}$, Hardianto Rahman $^{2}$, Umar $^{2}$, Siar Ni'mah ${ }^{1}$, Harmilawati $^{2}$ \\ ${ }^{1}$ Ushuluddin and Islamic Communication Al Quran and Tafsir Science, Sinjai, Indonesia \\ ${ }^{2}$ Tarbiyah and Teacher Training, Madrasah Ibtidaiyah Teacher Education, Sinjai, Indonesia \\ ${ }^{*}$ Corresponding author. Email: doktorfirdaus2018@gmail.com
}

\begin{abstract}
The importance of becoming a teacher in the Bugis Makassar community has increased from year to year. Teacher expectations are increasingly shifting from the ideal paradigm as educators to the pragmatic orientation of high salaries. The Bugis Makassar local culture value has a relation in the developing professionalism aspect of teachers not in a comprehensive approach. This paper aims to describe the perceptions of the Khonjo community and Sinjai Coast about the context of religious teachers through a socio-anthropological approach. The explorative descriptive qualitative paradigm was used in this study to get perspective, philosophical meanings, characteristics and values that could be nurtured at first. The decision of this study shows that if religious teachers are high ranking professional entities with their intrinsic value and religious literacy, their duties and roles are indispensable in the life of the community as religious and social educators, instructors (transfer of knowledge) and role models and even spiritual fathers. Religious teachers known as "tuangguru", "Tanggurua", "gurutta", "to acca", "anreguru", "anrong guru", and "to panrita" are community heritage that is relevant in the context of the teacher's life which all contain intelligence and intellectual meaning in the community version Promoting the role and function of religious teachers is important to make the concept of teachers and Bugis Makassar cultural values as a tool to shape selfprofessionalism in social life.
\end{abstract}

Keywords: religious teachers, Bugis Makassar Culture, revitalizing values

\section{INTRODUCTION}

Teacher and Lecturer, Law Article 1 verse 1 states that teachers are professional educators. Teachers need to be a positive role in teaching (transferring knowledge) and as role models in the changing global culture. Responsible for the country's intellectual life in instilling positive moral and cultural values. The role and professionalism of teachers should be noted as they are closely linked to the development of civilization and society, but the role and professionalism of teachers continue to be tested by the public as they differ from other occupations such as traders, politicians and technicians.

With regard to all spheres of life, the existence and expectation of teachers shifting the context from moral idealism to materialistic hedonism, they tend to be pragmatically oriented due to high teacher salaries and allowances. According to Atmadja, \& Atmadja, teachers have been trapped in homo hedonism and homo consumers [1]. Professionalism and competence as if measured by certification so that many people compete to become teachers. According to Maaranen, Kinaslahti, Byman, Jyrhama, Sintonen, the professional development of teacher educators is increasing globally [2].

The profession of teacher is highly needed by the high school graduates (SMA / MA / SMK) to choose their education and teacher training, especially in Sinjai district. The data shows the number of teacher candidates in the Faculty of Eduation and Teacher Training IAIM Sinjai in 2018-2019 academic year is 274 , in $2017-2018$ by 256 and in $2016-2017$ by 256 . Applicants for the candidates are quite attractive to the community, as well as a number of universities in South Sulawesi have grown over the years. There is a paradigm shift in the Sinjai community about teachers, many opinions expressing the success of a person being evaluated in their successful as a teacher.

Modern teachers seem like to lose their souls and ignore the noble values and their goals. As a result, his role and function shifted from ideal ideals as mandated by law, to professional teachers who educate the public. According to Banda \& Mutambo, perspectives on their role as graduates are often ignored [3].

In modern education orientations the teacher-driven learning is more concerned with the mere formation of the cognitive and sometimes neglects the moral aspects that the ideal teacher plays in life. Another fact is that teachers rarely internalize the cultural and moral values of their personalities in learning, as a result of their respectful, polite learner's attitude toward teachers and their parents' decline. [4] According to Segalo \& Rambuda, the right of teachers is diminished in the discipline of pupils due to the factors of safety and insecurity of teachers [5]. The findings of Woudstra, Rensburg, Visser \& Jordaan, show that there is a significant degree of intimidation of students to teachers that results in low work motivation [6]. This gives a bad image to education, especially the educational output of the cultural values and character of the people who have co-opted it. 
Concerns about the quality of teachers in several African countries and the importance of teacher education must not be separated from the ecological context and based on character values, macro education systems, diversity of resources and school culture [7]. The reflection in a decade on the development of teacher professionalism in several countries was also influenced by interactions, cultural traditions, policy environment, conditions and school culture.[8] Teachers are important to do reflective teaching in their learning practices [9]. Teacher professionalism can also be developed in a pedagogical context, namely teacher understanding, students' ability to learn, teaching material programs that are in harmony with the practice [10].

In the context of the philosophy of recovery using the Hindu religious texts, teachers must be able to control their minds and senses by optimizing their synergy with their intelligence.[1] Revitalizing the meaning and role of teachers based on the teachings of Sufism that can be oriented toward character education in which eligibility is responsible for moral education [11]. Teacher professionalism is influenced by educational policies that encourage the formation of values and culture as important responsibilities of teachers [12].

According to Susilawani Simply stated, a teacher's professionalism can be measured by his level of expertise and education wherever he is called as a religious teacher in the community [13]. The context of a teacher corresponding to the term "kiai" in the Muslim community is built on the fact that "kiai" has the power and knowledge of religion, morals and personalities that are in doubt in society [14].

Given the meaning and role of the above teacher it is important to revitalize it in the context of local cultural values. This study aims to validate the concept, role and function of religious teachers in the cultural heritage of Bugis Makassar with different contexts, the aim of which is to help strengthen the professionalism of religious teachers so that their traditions and values should be explored and as a knowledge discourse. Literature on anthropology in the footsteps of scholars, especially in South Sulawesi, was reported by Firdaus Muhammad, in his book "Anregurutta Sulselbar Scholars Literacy" with a charming gesture of supernatural gestures that teaches many examples of life. South Sulawesi scholarly literature as a supernatural treasure introduces the term "anregurutta", "gurutta", "topanrita" meaning "religious teacher" [15].

Such levels indicate that teachers have good religious knowledge and diversity. Only this concept tends to be less widely practiced in more concrete societies, especially modern-day teachers.

The existence of religious teachers in the perception of Khonjo and Sinjai Coast is interesting to learn and important for academic development, as both regions can represent different cultures, ethnicities and languages and the availability of informational resources. According to Ahmad Sewang, we lost the role of cleric still hidden in the wilderness, so we had to work hard to clear it. Sulselbar's past was excavated only $5 \%$, while $95 \%$ remained in the dark and uninterrupted wilderness.[15]

This study focuses on the perception of the Khonjo community and Sinjai Coast on the concept of religious teachers, their roles and functions. It is expected to respond to the lower morale and values of teachers. In addition to completing previous research, it is also a reference for readers, both teachers and policy makers, to be used as an important framework in restoring the role of professional teachers in special education institutions and the general public.

\section{METHODS}

This type of research is qualitative descriptive with a socioanthropological approach aimed at understanding the Khonjo and Sinjai coast community's perceptions of religious teachers. Symptoms are grouped into information carried out through descriptive-research [16]. The objects of the interview data collection were conducted in two different languages and dialects, namely the Khonjo language community in the West Sinjai region, part of Central Sinjai and Sinjai Borong. The coastal areas of Sinjai are North Sinjai, East Sinjai and Kab. Southern Bone (in Bugis) by gaining public perception, philosophical meaning, role and function and values inherent in teachers through the selection of informants by the snowball.

Data collection through in-depth interviews, documentary studies (documentation), audiovisuals and Focus Group Discussion (FGD). In-depth interviews of thirteen informants; Mustang (R-1). Abdul Rahman (R-2), Ahmadiyyah (R-3), Puang Sangkala (R-4), Petta Colli. (R5), Baco Bolong (R-6), Hasnah (R-7), Suciani (R-8), Suryani (R-9), Andi Nurmalasari (R-10), Puang Keseng (R-11), Muh. Tahir (R-12) and Darmawati (R-13). This documentary study is conducted by examining images and other sources of audiovisual understandings through the medium of portable digital recorders and youtube. Focus Group discussions were conducted with historians and cultural figures Muhannis and Muh. Anis Data collected were analyzed using Miles, Huberman \& Saldana interactive model through [17]. State data by selecting and facilitating field notes, interview transcripts, documents and empirical facts. Providing data on information about teachers to draw conclusions and actions. Conclude by getting a clear picture of the perceptions of the Khonjo and Sinjai Coast religious teachers.

\section{RESULTS AND DISCUSSION}

\subsection{The Concept of Community and Teacher Perceptions}

Theories of perception, community and teachers are used in this study. Some experts emphasize the theory of perception as suggested by Rahmat as the experience of objects, events or relationships gained by concluding information and interpreting messages, perceptions are also determined by personal and situational factors [18]. Miftah Thoha defines perception as the cognitive process experienced by everyone in understanding information about their environment, whether through sight, hearing, appreciation, feeling and smell. From the perception acquired through the senses it becomes information as a framework for action [19]. 
According to Slameto interpret processes that involve the entry of messages or information into the brain [20]. Through iterative processes humans make connections with their environment.

Society is a combination of individuals that form a larger group. Combined variations include household, village, ethnic, national; traditional variations, such as ethnic, religious, and particular ethnic groups, to modern ones, such as legal institutions, political parties, and others. The group of individuals who form a comprehensive community or unit of society is bound by certain values and codes of ethics or philosophy and way of life [21]. Individual groups or groups have a common bond and shared interests as a society [22]. Theories about teachers generally do not change much in the context, teachers play a role in the growth of various human dimensions. As a theory is presented Tafsir, if the teacher is the one responsible for student development in an effort to develop all potential (sense), cognitive (copyright) and psychomotor (intention) [23]. The term teacher is an educator who is a character, model of role and identity of students and their environment; teachers have certain standards of personal quality [24]. Mujib argues that educators are spiritual fathers to students, who provide food with knowledge, cultivate good morals, and correct bad behavior [25]. Teachers are synonymous with "kiai" in Islamic boarding schools that traditionally carry out religious education among children (santri) [26]. According to Getteng, cultural persons who work as teachers (educators) are formally responsible for advancing the mission and quality of education as well as the values and goals of society [27].

\subsection{Conception of Religious Teachers in the Bugis Makassar Society}

Demographically, Sinjai district, South Sulawesi Province is inhabited by the majority of ethnic Bugis communities. In other parts, there are Khonjo people with a mixed ethnic group of Bugis and Makassarese. According to Ningsih S., the Khonjo language is the local language in the sub Makassar and Selayar [28].

In social anthropology, the Indonesian people are familiar with the terms about "guru-agama" or various titles, including "Tuan guru" in Lombok, "Buya" in West Sumatra, "Ajengan" in West Java, "Gure" in Aceh, "Wali" or "Sunan" in Java which is pinned to the scholars with high religious scientific capacity is also called "kiyai". The people of South Sulawesi know the term "guru agama" (religion teacher) in a variety of ways, including the term "muballigh and kiyai". The use of the word "kiyai" is identical to the teacher in the field of Islamic religion. In a higher order, Firdaus Muhammad exemplifies the use of $\mathrm{KH}$ (Kiyai Haji) to become Anregurutta Haji (AGH) where the term AGH is determined based on the decision by MUI South Sulawesi [15], such as AGH KH. Jamaluddin Amin.

Terms related to religion teachers in the Khonjo Society and the Sinjai Coast which have philosophical meanings, such as "tuanguru or Tanggurua". This mention means a teacher who shows "he is a teacher" and works as a teacher (R-1). According to Zulkifli, the people of Lombok also recognize the title of "tuan guru" is someone who is able to protect the community or educate, for example Tuan Guru KH. Abdul Majdi [29]. In terms of the Sinjai coastal community; known the mention of "gurutta", "tuan gurutta", "puang gurutta", "puang gurue", the teachers are considered the most meritorious in teaching their religious knowledge (R-2), with the addition of the prefix "puang", "tuan" the suffix "ta" means our teacher, a teacher for many people (R-3). Such mention implies that people are respected, showing attitudes and respect for someone who is considered a teacher with all the inherent positive qualities that affect the mentality and attitudes of others. "Some elementary schools in the Batu Mimbalo Region, students in the school environment are always taught to call teachers as "puang" the reason in order to get them accustomed to recognizing and respecting teachers as parents who are always respected" (R-13).

In terminology "tuanguru", "puang'guru" implies a person who is considered honorable with a capacity as a teacher, for example being able to "digugu" is someone who can be emulated and followed because of the ability to transmit science and knowledge to others even considered to be instrumental in teaching religious knowledge. From some of the terms above can be concluded if the religion teacher occupies an important position as an ideal human being, respected because of his knowledge and ability to make learning for many people in a society.

In the social culture of the Bugis community it is also called "To Acca", which means a smart and intelligent person or "caradde" in the social culture of the Khonjo Society. Such a term is pinned to the teacher as "guru to acca" or "guru caradde", because in essence the teacher has intelligence and virtuous (R-4). The title as "To Acca, caradde" is an acknowledgment of one's knowledge and religious knowledge (R-5).

These terms develop along with learning and teaching activities. "Anreguru" is also understood as a learning activity or "mattareka" (R-6), in Bugis language, it can also mean direct learning activities in a person (R-7). History and development of Makassar Bugis community education activities in the concept of "anreguru" or "massapa paddisengeng" or "pangngisengang" then "anreguru" is a hereditary title pinned to prosecutors of knowledge, explore and practice the science of religion and other knowledge. The term "anreguru," "anrong guru" is a form of appreciation for teachers in the past (R-8).

"Anreguru" in (Bugis language) and "anrong guru" in (Khonjo language), "anre" can mean eating, and "anrong" means mother, the teacher is the teacher. The fusion of words into "anreguru" and / or "anrong guru" can be interpreted as "mahaguru" can also mean to deepen the knowledge of a teacher (R-9). These two language terms have in common the similarity of the teacher or professor with all their capacities while the difference lies in the scientific level of a teacher "Tangguru, Gurutta, Anreguru or Anrong Guru". Khonjo and coastal communities view teachers as respectable human beings. His activities are noble, humans with religious knowledge and good social attitudes (R-10), teachers who are full of love and affection for students (R11). This view confirms the term "tuan guru" or "anre guru" as a man of knowledge without recognizing the difference with the general teacher as the modern version today because technically the teacher has a dual role as an educator and 
technical implementer of learning both in school institutions and society at large.

The religion teacher called "to panrita" etymologically according to Ide Said, Halim mentions the term "topanrita" means witness or witnessing, it can also mean an ability possessed (technical expertise) such as experts in the field of boat making (panrita lopi) [30]. besides that, it also means a large "ulama" or "kiai" who is devoted to the Bugis "ulama". "Topanrita" certainly has the criteria of an intelligent human being "caradde" who dares to make decisions (warani) and has assets (sugi) because they are used as a reference for the community

"Topanrita" is also identified as a role model that can be used as a (role model) in society because it has moral qualities so that many people crave their children to become "topanrita" when they are adults, when they reach the level of religious knowledge and high moral quality has deserved to be called the "topanrita" of the community [30]. If you have reached this level, then it is considered as a success in a society. This context shows as a reference for others where the exemplary, inner expertise, knowledge and teachings of profound religion he has.

Kadir states that in the formal social strata of the BugisMakassar caste, there are seven structures, namely "Anakarung" (aristocrats), "Panrita" (ulama), To Acca (intellectual), To Sogi (rich people), To Warani (jawara), To Maradeka (free people), and Ata (servants). In the hierarchy of scientific transmission "anregurutta" became the highest reference among the religious experts below. Gurutta becomes a reference for religion teachers and the general public, while anreguru is a reference for the community, religion teachers, and gurutta. The community, the clerics, and the "gurutta" have their respective references in matters that cannot be solved by themselves. The teacher-student network among the scholars can be seen from the habits of those who refer to those in Islamic matters. Panrita is used for scholars who arrive at the "anregurutta" stage, the highest level of scholarship among the Bugis. In this position "panrita" shows the social elite of the level of "anakarung" [31].

In the regional context (Sinjai) also called the earth "panrita kitta" can mean areas that have the potential to produce or create the scholars with qualified religious knowledge or in the modern version can be referred to as the center of the book and commentators. As the mention of "bumi panrita lopi" for people who are experts in the dimensions of making Phinisi boats in Bulukumba.

The terms about the religion teacher in society contain intellectual meaning (intellectual) in the modern version where a person is at the same time a role model because of good religious scholarship and a reflection of the behavior (gau'gaukang) or (ampe-ampe). Ruslam \& Santim also reported the role of "Tuanguru, gurutta, to acca, anrenguru, to panrita", are "ulama" and main actors in the life of the people. "Ulama" is present in every beat of the life of the ummah in the various figures. They acted out the life scenario revealed by Allah SWT. Most of the scenarios are portrayed and exemplified in the history of the life of the Prophet Muhammad SAW. A link that places the "ulama" as the heirs of the prophet. "Ulama" present in a faqih, ulama can appear as a dai, "ulama" present as a Sufi and "ulama" present as a warrior [32].
In this position the existence of the teacher is a social entity and has a close relationship with the community to create harmony through the role of teaching and education as its main responsibility. In the micro context the teacher and student interactions are equally beneficial. The teacher performs transformative tasks and is respected in his profession, while students build harmonious relationships and develop values. This position will determine the direction and quality of the nation's generation.

The concept of teacher training from the term "Tuanguru, Tanggurua, gurutta, to acca, caradde', anrenguru", or "to panrita" in the view of the Khonjo community and the Sinjai Coastal has been interpreted as a high-level human title with all intrinsic values that are intrinsic in social life. Its role and function as an intermediary out of the shackles of concern and livelihood of many people both spirituality, mental and humanity. The religion teacher shows the figure as a scientific and spiritual educator, it is a valuable inheritance because the role of the "ulama" (teacher) in the educational practices of the past in various layers of society is proof of the ability of the teachers or scholars, "topanrita" because of their role and function as community partners in various ways.

In this context, it complements the arguments of Banda \& Mutambo, if teachers in traditional societies have good care for children, especially in lifelong moral learning, in middle society, it transmits the knowledge and culture of elite groups, in industrial societies more on development skills [3]. In line with the conceptualization of Fourie \& Deacon, the meaning and purpose of the teacher in the context of work is the transfer of knowledge, building a positive cultural life in students [33].

Giving birth to teachers who have competence in the Bugis community as the capacity of "Anreguru, Topanrita" and / or scholars, according to Ahmad, Halim, at least include scientific competence (religious knowledge), social competence (aspects of religious practice), and moral competence (personality). While the three main characteristics are humility in science, sincerity in charity, and being careful in maintaining the sanctity of morals [34], [30].

In everyday life the nature of "guru agama" is reflected as; "Macca" (smart), "makessing sifa'na" (good character), "tau malempu" (honest person), "tau mafajang" (smart in learning and teaching), "tau mappidesyeng" (likes to improve and remind) (R-4). "Matanre paddisenenna" (knowledgeable), "madesyeppa ampe-ampena" (good attitude, behavior), "masopang maccaritai" (polite speech), and "makuaimanna" (strong faith) (R-5). "Mabbela-bela na mabonga" (happy to hang out and joke) (R-6). "Tau panrita, macca, baji gau'na" (from our teacher taking a good example) (R-11). "Tena passilaengang", (not discriminating and generous) (R-7). "Adelee appaguruii" (fairness in teaching) (R-12). "akamaseang" (loving students), "tau tinggi pangisengang sallanna" (high Islamic knowledge) (R13). The teacher has a respectable attitude in the community, the teacher's duty is very important than the profession of entrepreneurs and village officials (R-10). Hamid's report if Makassar Bugis people in rural areas emphasize high moral attitudes [35].

The above findings confirm the relevance of the values of the wisdom of the Bugis so that it can be more respected by 
the community, namely; (1). "Mappakalebbi" (giving awards, subtlety and hospitality), (2). "Mappakaraja" (greeting full of appreciation), (3). "Malebbi pangkaukeng" (displaying exemplary), (4). "Mattulung temmatuttuu", (likes to help and does not bring up), (5). "Malaabo Risitinajae," (friendly in providing assistance and not excessive), (6). "Matinuulu" (trustworthy, diligent and thorough in his duties), (7). "Macca na macaradde" (smart and full of creativity), (8). "Temmappassilaingeng" (showing justice to anyone), (9). "Temmabangka" (not showing arrogance with background), (10). "Tetakabboro"" (not arrogant), (11). "Temmasereati" (showing his happy nature to anyone), (12). "Teppabelleng" (not promising that cannot be fulfilled), (13). "Temmaboorro" (not showing off any advantages possessed) [36].

In social relations, "anregutu," "topanrita" profile of the teacher's life prioritizes the principle of "sifakatau" (humanizing others), "sifakainge" (reminding each other), "sifakalebbi" (glorifying each other), "sifatokkong" (helping each other). Besides "alempureng" (honesty), "amaccang" (intellectual), "assitinajang" (propriety), "agettengeng" (determination), "awaraningen", (courage), and "Madeceng kalawing ati" (good heart's content) are the emphasis on each individual, especially religion teachers in the Makassar Bugis culture.

Ideally, such values and competencies are important to be held firmly by teachers to achieve professionalism and high dedication as "tuan guru" even further as the center of "anreguru" or "topanrita" level. His position as a role model as well as community leaders, inspirations, intellectuals, mentors as well as movers in change and development, an exemplary example so that he is a personification of moral character "ampe-ampe madeceng" in the environment of community and school life.

\section{CONCLUSION}

Islamic religion teachers contain philosophical meaning and value of local cultural character as a legacy of various terms. The terms, functions, roles and values of wisdom inherent in fact lead directly to the traditions of the community as wise, high-quality learners who are able to become figures who present as spreaders of virtue. The above conception is believed to be an ideal alternative to an important framework (frame of reference) for teachers in growing the character of prospective teachers and actualizing their tasks and roles. Community culture has been embedded if the teacher is a respected profession that will always be embedded in the teacher and prospective teachers in the present.

The conception of religion teachers in the context of the Bugis Makassar culture and its implementation in various aspects, both the school and social life aspects of the community is important for the support of various parties including stakeholders in implementing better policies. This ideal revitalization requires the introduction and orientation of coaching as an essential program to build the paradigm of religion teachers in the transformation of science, knowledge and role models in the millennial generation without losing identity, tradition of values and positive culture in the context of local wisdom.
Conception, values, roles and functions of religion teachers become an alternative effort to strengthen local cultural character amidst changes in values so that they can contribute to the treasury of teacher education and strengthen educational practices in various contexts, both within the family, school and society at large. Exploration of the essential meaning and philosophy of religion teachers in the cultural context of local and modern communities deserves to be expanded and deepened through further research so as to better complement the perspective of this study.

\section{ACKNOWLEDGMENT}

We are grateful this study was supported by the Institute of Research and Community Services (LP2M) of the Islamic Institute of Muhammadiyah Sinjai.

\section{REFERENCES}

[1] A. T. Atmadja, \&, and N. B. Atmadja, "Guru: Memperkaya Atau Menyejahterakan? (Perspektif Semiotika Komunikasi)," J. Pendidik. dan Pengajaran Undiksa, no. 1, pp. 628-649, 2008.

[2] R. J. \& S. S. Katriina Maaranen, Heikki Kynäslahti, Reijo Byman, "Teacher education matters: Finnish teacher educators' concerns, beliefs, and values," Eur. J. Teach. Educ., vol. 42, no. 2, pp. 211-227, 2019.

[3] M. Banda, P. P. Mutambo, [ A Hargreaves, and M. Fullan, "The Role of the Teacher: Philosophical Perspectives," Int. J. Humanit. Soc. Sci. Educ., vol. 2, no. 10, p. $2349,2015$.

[4] T. News, "No Title," ttp://makassar.tribunnews.com, 2016. [Online]. Available: http://makassar.tribunnews.com/2016/ $10 / 23 /$

[5] L. Segalo and A. M. Rambuda, "South african public school teachers' views on right to discipline learners," South African J. Educ., vol. 38, no. 2, pp. 17, 2018.

[6] M. H. Woudstra, E. J. Van Rensburg, M. Visser, and J. Jordaan, "Learner-to-teacher bullying as a potential factor influencing teachers' mental health," South African J. Educ., vol. 38, no. 1, pp. 1-10, 2018.

[7] K. Akyeampong, "Reconceptualizing teacher education in the Sub-saharan african context," J. Int. Coop. Educ., vol. 5, no. 1, pp. 11-30, 2002. 
[24] E. Mulyasa, Menjadi Guru Profesional. Bandung: Remaja Rosdakarya, 2006.

[25] A. Mujib, Ilmu Pendidikan Islam. Jakarta: Kencana Prenada Media, 2006.

[26] C. Pelras, Manusia Bugis. Jakarta: Penerbit Nalar, 2006.

[27] A. R. Getteng, Pendidikan Islam di Sulawesi Selatan (Tinjauan Historis dan Tradisional hingga Modern). Yogyakarta: Graha Guru, 2005.

[28] Sri Ningsih, "Factors Contributing To the Maintenance of Konjo Language in Heterogeneous Area of Bulukumba Regency (In the Perspective of Ethnolinguistic Vitality)," Ethical Ling., vol. 3, no. 2, pp. 103-113, 2016.

[29] Zulkifli, Gelar Dalam Islam. Yogyakarta: Pinus Book Publisher, 2009.

[30] W. Halim, “Arung, Topanrita Dan Anregurutta Dalam Masyarakat Bugis Abad Xx,” Al-Ulum, vol. 12, no. 2, pp. 317-334, 2012.

[31] Ilham Kadir, "Gurutta, Anreguru, Panrita,” 2013. .

[32] M. R. dan W. Santing, Ulama Sulawesi Selatan; Biografi, Pendidikan dan Dakwah. Makassar: Komisi Informasi dan Komunikasi MUI Sul-Sel, 2007.

[33] M. Fourie and E. Deacon, "Meaning in work of secondary school teachers: A qualitative study," South African J. Educ., vol. 35, no. 3, pp. 1-8, 2015.

[34] A. K. Ahmad, Ulama Bugis. Makassar: Indobis Publishing, 2008.

[35] A. Hamid, Syekh Yusuf Seorang Ulama, Sufi dan Pejuang. Jakarta: Yayasan Obor Indonesia, 1994.

[36] N. Nawawi, Cendikia Muslimah Nusantara dalam Buku, Refeksi 75 Tahun Prof. Dr. Hj. Andi Rasdiyanah-Meneguhkan Eksistensi Alauddin. Makassar: Pustaka Al-Zikra UIN Alauddin, 2010.
[19] M. Thoha, Perilaku Organisasi: Konsep Dasar dan Aplikasinya. Jakarta: Rajawali Press, 2010.

[20] Slameto, Belajar dan Faktor-Faktor yang Mempengaruhinya. Jakarta: Rineka Cipta, 1995.

[21] A. Bustanuddin, Islam dan Pembangunan (Islam dan Muslim Serial Esai Sosiologi Agama I. Jakarta: Raja Grafindo Persada, 2007.

[22] M. O. A.-T. Al-Syaibany, Filsafat Pendidikan Islam. Jakarta: Bulan Bintang, 1979.

[23] Ahmad Tafsir, Ilmu Pendidikan Dalam Perspektif Islam. Bandung: Remaja Rosdakarya, 1992. 